\title{
Critical Analysis of Governance, Economic Freedom, and Human Capital Implications on Sustainable Economic Growth: Evidence from Sub-Saharan
} Africa

\author{
Yusuf Ayotunde Ayodeji \\ Cyprus International University KKTC Mersin, 10, Turkey.
}

Corresponding : ayotunde725@gmail.com

Received: 05, August, 2021

Accepted: 14, August, 2021

Published: 15August 2021

\begin{abstract}
In the recent time, the attention of scholars have shifted towards deeper understanding of factors that drives the achievement of sustainable economic growth, but yet factors such as governance, economic freedom, and human capital have not been exhaustively investigated, especially within the context of Sub-Saharan Africa (SSA). Thus, this study investigates the implications of governance, economic freedom, and human capital on the sustainability of economic growth in the SSA, usingpanel data that spanned between 1996 and 2018, and employed a Pooled Mean Group (PMG) estimator for the analysis. This study found governance, economic, and human capital to have a positive and significant causal relationship with economic growth in the long-run, while only economic freedom was found to have a negative and significant causal relationship with economic growth in the short-run. In addition, this study found that in case of disequilibrium, the model has a convergent speed of adjustment of about $10.8 \%$. The study implications were discussed in the study.
\end{abstract}

Keywords: Governance; Economic freedom; Human capital; Economic growth; Sub-Saharan Africa.

\section{Introduction}

The issue of characteristics, sources of wealth, and prosperity of countries still remains one of the main interest areas of researchers, especially the economist. Dated back to the early 1980s, institutional analysis have been applied to the study of economic and social performance by the economists and economic historians (Medina-Moral and Montes-Gan, 2018), thus, Compton, Giedeman, \& Hoover (2011) observed that studies have revealed the important impact of institutions on the incentive for accumulation, innovation and the integration of novel technologies in a country's economy. This view corroborated the position of Berggren (2003) who opined that researcher interest in determining the relationship between governance and development as snowballed into development of new ideas, theoretical and empirical findings, and new databases.

Similarly, the understanding of human capital and sustainable economic development has long been investigated (Benhabib and Spiegel, 1994; De la Fuente\&Domenech, 2000, 2006; Mankiw et al. 1992; Pelinescu, 2015; Riley, 2012; Odugbesan\&Rjoub, 2019). According to Omojimite (2011), two sides of research findings exist in the literature. First, those scholars that believes the development of human capital through education and training has an impact on the economic growth by imparting "general attitudes", "specific skill", fertility reduction and improves people's standard of living (Adebiyi and Oladele, 2005; Barrow and Lee, 1993; Lucas, 1988, Rehme, 2007; Romer, 1990).
Secondly, there is group of studies that established that in spite of the notable expansion on the educational facilities, especially in the developed countries, it does not determine the increase and stability of the "Gross Domestic Product" (GDP) (Ali-Abdel, 2005; Benhabib and Spiegel, 1994; Pritchett, 1999).

The study of Benhabib and Spiegel (1994) revealed that the inclusion of human capital as a factor of production in the CoobGouglass model results to the non-significance of its impact on economic development, however, if the impact of human capital on total factor productivity is being taken into consideration, there are two possible effects: i) human capital has impact on innovation (Romer, 1990); ii) Pelinescu(2015) shows that the rate of technology diffusion is being influenced by human capital. These was supported in the study of Funke and Strulik (2000) who demonstrated that a percentage increase in the capital stock will results to about $0.13 \%$ increase in the rate of development and posited that process of advancement in technology development of some countries depends largely on the country's stock of human capital.

Rode and Coll (2012) posited that the achievement of success by any nation can be significantly influenced by the man-made institutions. To date, majority of the formal economic and political institutions investigated in the studies are encompassed in the concept of governance and economic freedom. Whereas, the SSA region which accommodates large percentage of developing countries are mostly in the process of development and thus requires a research-informed policy to guide the sustainable 
economic growth of the region, but the research in this aspect is scant in the literature.

The main focus of this study is to empirically investigate the implication of governance (using the governance indicator developed by Kaufman, Kray, and Mastruzzi, 2010), and consistently used in some studies (Odugbesan\&Rjoub, 2020; Odugbesan et al. 2021), economic freedom (employed the indicator developed by Fraser Institute - James et al. 2012), and the human capital (index from Penn World Table - Feenstra, Inklaar, and Timmer, 2015) on the sustainable economic growth. This empirical study will allow for further understanding to know the contributions of these variables to the economic growth sustainability in Sub-Saharan Africa (SSA) region. The contribution of this study will be in two folds: first, it will address the gap in the literature in respect of investigating the governance, economic freedom and human capital in the context of SSA which have not been previously investigated. Secondly, this study employed dynamic panel data model for the analysis in order to address the issue of heterogeneity, and also since the issue of sustainability goes beyond a border, it becomes imperative to consider the region using a panel data, so as to determine how the nature of governance, economic freedom and human capital in the region contributes to the sustainability of economic growth in the region. The findings from this present study will serve as a guide for policy makers in SSA countries to fully understand the implications of governance, economic freedom and human capital as it relates to the achievement of sustainable growth. Thus, their policy formulation will be an informed policy anchored on some empirical grounded findings.

The remainder of the paper is structured as follows: the relevant literatures are reviewed in section 2. Section 3 shows the description of the data employed for the study and model of estimations. Section 4 consists of the empirical findings from the application of appropriate panel data estimators. The discussion and conclusion rounded up the paper in Section 5.

\section{Literature review}

The study of Knack and Keefer (1995) opined that the quality of governance of any nation is significant to the explanation of investment rate, which is an indication that one way of encouraging economic development as identified by Olson et al. (2000) is through the improvement of the capital market and investment environment. However, Evans and Rauch (1999) identified other avenue through which good governance can enhance performance of economic, for instance a stable bureaucratic encourage investment in the long-term in the private sector; professionalization of bureaucratic promotes public facilities investment (Rauch, 1995); corruption reduction and promotes productive investment (Campos et al. 1999; Dahlstrom et al. 2012); Zhang and Yu (2009) opined that optimization of resource allocation is being driven by a good economic power structure; also Liu et al. (2013) believes the structure of political power influence economy system and policy; the decentralization of fiscal leads to formal incentive and regional competition (Shao, 2016); resource allocation is influenced by the marketization; and, good governance also gives support to government effectively through the provision of tax, services, product, and so on. All these are an indication that governance is a social infrastructure that plays a significant function in the growth of economy (Al Mamum et al. 2017; Fayissa\&Nsiah, 2013; Hall \& Jones, 1999) through systems and government policies (Adedokun, 2017; Setayesh\&Daryaei, 2017).
In reference to some empirical studies, the lower per capital GDP did not only make a country to be underdeveloped, but also a good governance enable developing countries to make adequate use of their "late-mover" advantage to achieve "catch-up effect", for the achievement of economic which Murrell and Olson (1991) opined could be faster than that of developed countries. According to Zhang and Wang (2013), in a situation where the "World Governance Index" (WGI) is lower, there will be high increase in the per capital GDP where there is a unit increase of governance, while in a case of higher WGI, there will be smaller improvement of per capital GDP. In comparison to the countries with high quality of governance, the positive impact of governance index on economic development is much greater and significant in countries lesser quality of governance (Seldadyo et al. 2007).

Thus, it is mostly believed among the scholars that the quality of governance and economic growth relationship is complicated, which could be non-monotonous (Huynh \&Jacho-Chavez, 2009). This was revealed in a recent study by Liu et al. (2018) who found a positive impact of governance quality on economic growth, but also demonstrated that a diminishing marginal returns was presented governance quality, which implies that "the high-speed economic growth effect becomes less and less, while the high quality economic development effect becomes more and more" (Liu et al. 2018, p. 1). It is in view of the empirical studies that support the positive influence of governance on the economic growth that motivates scholars to investigate if the governance could propel the achievement of sustainable development (AlBassam, 2013; Dhaoui, 2019; Glass \&Newig, 2019; Odugbesan and Rjoub, 2019). These studies posited that quality governance contributes significantly to the achievement of sustainable economic development.

The studies that investigate the relationship between economic freedom and economic growth abound in the literature. A panel study least square method was employed by Islam (1996) to established a significant impact of economic freedom on the per capital income of countries that are categorized as low income, middle income and high-income. It was found in the study that the influence of economic freedom on economic growth relies on the income levels of the countries. Similar study was conducted by Easton and Walker (1997) using panel data of 57 countries and the result shows that the property rights, income of the people and economic growth are spurred by the market socialism. Another author attempted the study of the relationship using different component of economic freedom index and the results found were mixed (Ayal\&Karras, 1998; Carlsson\&Lundstrom, 2002; Derbel, Abdelkafi and Chkir, 2011).

In contrast, the study of Ali and Crain (2002) found a negative influence of economic freedom on economic growth in their study. The study argued that "economic freedom consequent on low economic growth rate but political freedom and civil liberty boost economic growth". The direct and indirect influence of economic growth was examined by Doucouliagos and Ulubasoglu (2006) using cross-sectional data of 82 countries. The authors found a positive and direct influence of economic freedom on economic growth, as well as the positive and indirect impact on economic development through the physical capital simulation. It was demonstrated in the study of Justesen (2008) that there exists a positive and significant causal relationship between economic freedom and economic growth, while also exist a positive but weak causal relationship between economic growth and economic freedom.

A panel of 141 countries was investigated by Williamson and Mathers (2011) to determine the influence of economic freedom 
and culture on economic development, and the study found a positive effect of economic freedom on economic growth. This finding was corroborated by some recent studies who demonstrated that the effect of economic freedom has a significant effect on the sustainable development of any nation (Brkic et al. 2020; Graafland, 2020; Mushtaq and Ali Khan, 2018; Odugbesan et al. 2021). The study of Medina-Moral and Montes-Gan (2018) found economic freedom in their study to be a significant factor in all developmental stages. In addition, the investigation whether economic freedom lead or lag economic growth in Bangladesh was conducted and the results shows that economic freedom clearly lead and improve economic growth (Tanin and Masih, 2017). Similarly, a long-run relationship between economic freedom and economic growth was found in a study conducted by Bayar (2017) in the transition economies of European Union. Though studies abound on this subject, but most of the studies are not within the context of SSA and owing to the nature of the region which is highly dominated by developing countries, it becomes imperative to empirically investigate the influence of economic freedom to the sustainability of the economic growth in the region.

Moreover, the interest of researcher on the influence of human capital on economic growth remains highly discussed in the literature. Some author opined that human capital is critical to the achievement of economic growth that will be sustainable (Absalyamova et al. 2015; Ciuhu, 2016; Odugbesan\&Rjoub, 2019; Slaus and Jacob, 2011). These studies posited that human capital accelerates the process of technology innovations couple with the capacity to guide against the deterioration of the environment. In addition, it promotes the evolution to a reduced "material-resourceintensive", "service-based economy". Human capital is believing to also fosters the emergency of a well-informed, social conscious people that could adequately understand and respond to the problem of sustainability through an increase emphasis on higher levels of education (Odugbesan\&Rjoub, 2020; Slaus and Jacob, 2011). Pelinescu (2015) observed that labor productivity is considered to be an exogenous factor which relies on the ration between labor force and physical in addition to other factor as shows in the "classical theory of economic growth", however, the positive impact of education on potential growth of productivity was not considered in the calculation. It was in respect of this that the new economic growth theory was developed to address the shortcomings and it placed emphasis on the significance of human capital on the economic growth in the long-run. An empirical study by De la Fuente and Domenech $(2000,2006)$ found a positive and significant correlation between human capital and economic growth. Similar result was found by Bassanini and Scarpetta (2001) who demonstrated in their study on the series of OECD data that a year increase in the duration of schooling will results to a $6 \%$ increase in the GDP per capital.

In addition, the empirical nexus between human capital and economic growth across some countries was examined by FreireSeren (2001). The study posited that the process of human capital accumulation is being positively influenced by the level of income. Similar study was conducted by Aka and Dumont (2008) in USA over the period 1929-1996, and the study demonstrated a bidirectional causality between human capital and economic growth. Meanwhile, a regional study on European Union was carried out to determine the nexus between human capital and regional economic growth. The study found that the economic performance experienced in the region was as a result of the increase in overeducation (Ramos, Surinach, and Artis, 2009), while the study of
Alatas and Cakir (2016) on developing countries found human capital to positively influence economic growth. The discussion from the above is an indication that a region with abundant stock of human capital tends to achieve a sustainable economic growth which some studies has already established a significant relationship between the human capital and sustainable development (Odugbesan and Rjoub, 2019a). Though, studies abound on the relationship between human capital and economic growth, but within the context of SSA has not been exhaustively investigated, thus the need for more studies.

\section{Data and methods}

\subsection{Data}

The study aim is to investigate the implications of governance, economic freedom, and human capital in the sustainability of economic growth in SSA. In order to achieve the study objective, governance index, economic freedom, and human capital index were selected as variables to determine their impact on the economic growth sustainability. The governance index was measured with six indices (voice and accountability, control of corruption, rule of law, regulatory quality, absence of violence/terrorism, and government effectiveness and political stability). The measure for governance was developed by Kaufmann, Kraay\&Mastruzzi (2010) and in order to compose the index, "Principal Component Analysis" (PCA) was employed. The economic freedom was measured with the "Economic Freedom of the World Index, (EFWI)" that was developed by the Fraser Institute which according to Gwartney et al. (2019) is for economic freedom measurement, meanwhile, the composite score of 24 policy areas which are categorized into five areas of economic freedom, and in turn constructed into an index. The index was constructed from the variables that are equally weighted and aggregated into an average value that is between 1 (least free) to 10 (most free). The use of human capital index computed by Feenstra et al. (2015) for Penn World Table (PWT) version 9.1 was utilized. This was as result of the arguments in the literature in respect of the consensus measurement for human capital (Feenstraet al. 2015; Barro and Lee, 2013), and the index has been utilized in some previous studies (Odugbesan and Rjoub, 2019a). Lastly, the economic growth was measured with the GDP per capital (constant 2010 US\$). The GDP was sourced from World Bank Development Indicator (2020), the governance from World Governance Indicator (2020), the human capital from Penn World Table (2020), while the economic freedom data was sourced from the Fraser Institute database. The data are yearly data that covers the period from 1990 to 2018 , which includes 32 countries in SSA, meanwhile the choice of countries included are based on the data availability for the period under observation.

As depicted in Table 1, the mean value for the economic freedom shows that the region is averagely free for economic. The minimum and maximum economic freedom indexes are 2.89 and 8.12 respectively. Meanwhile, the standard deviation (.862) is an indication that the variations among the countries in the panel in terms of the economic freedom index are very small. Moreover, human capital index has a minimum value of 1.053 and a maximum value of 2.89 . The mean value is 1.75 while the standard deviation is .442 . The low value of standard deviation is an indication that the human capital among the countries is almost similar. 
Table 1: Descriptive statistic

\begin{tabular}{|l|l|l|l|l|l|}
\hline Variable & Obs & Mean & Std. Dev. & Minimum & Maximum \\
\hline Eco_Fre & 736 & 5.894 & .862 & 2.889 & 8.117 \\
\hline HCI & 736 & 1.748 & .442 & 1.053 & 2.885 \\
\hline GDP & 736 & 1925.73 & 2418.99 & 187.507 & 11949.28 \\
\hline Gov_index & 736 & $2.17 \mathrm{e}-16$ & 2.224 & -5.629 & 5.436 \\
\hline
\end{tabular}

Eco_Fre $=$ economic freedom index, HCI $=$ human capital index, $\operatorname{lnGDP}=$ natural log of gross domestic product, Gov_index $=$ governance index. Std. Dev = standard deviation

Source: Author's computation

\subsection{Method}

In line with the study of Shao (2016) and Seldayo et al. (2010), this study puts forwards the econometric models that describe the relationship between economic growth, governance, economic freedom, and human capital in SSA as follows:

$\mathrm{GDP}_{\text {it }}=\beta_{0}+\beta_{1} \mathrm{GOVI}_{\mathrm{it}}+\beta_{2} \mathrm{EFI}_{\mathrm{it}}+\beta_{3} \mathrm{HCI}+\varepsilon_{\text {it }}$

Where, GDP is the "Gross Domestic Product Per Capital (Constant 2010 US\$)"; GOVI is the index of "voice and accountability, rule of law, regulatory quality, control of corruption, government effectiveness, and political stability and absence of violence/terrorism"; EFI is the economic freedom index; while, HCI is the human capital index. The subscript $i$ and $t$ represents the specific country in the panel and the time respectively, while $\varepsilon$ denotes the error term.

Prior to the estimation, the order of integration of the variable was examined using the Levin-Lin-Chu (LLC) (2002) and Im-PesaranShin (IPS) (2003) unit root tests. The assumption of common autoregressive parameters for all cross-sections is known to be peculiar to the LLC, while the IPS is anchored on the assumption that there is variation of the autoregressive parameters among the cross-sections. Furthermore, it is often opined in the literature that in most cases panel data are cross-sectional independent, especially when the number of cross-section is large (Pesaran, Schuermann, \& Weiner, 2004). Pesaran et al. (2004) thus submitted that it is essential to account for the cross-sectional dependence in our estimation in order to avoid loss of estimator efficiency and bias result. It is in view of this that we employed the use of BreuschPagan, Pesaran scaled LM, Bias-corrected scaled LM, and Pesaran $\mathrm{CD}$ to test the cross-sectional dependency in our data. In addition, the existence of long-run relationship among the variables was examined using the Pedronicointegration test, which some studies posited that it was based on the residuals emanating from the estimation of long-run static regression (Adusah-Poku, 2016; Odugbesan\&Rjoub, 2020; Odugbesan et al. 2021). Thus, this Pedronicointegration test was employed to examine the existence of long-run relationship among the variables in this study.

The empirical estimation of this study was based on the "Pooled Mean Group (PMG) approach in the panel ARDL framework (2004). In this methodology by Pesaran et al. (2004), three estimators (PMG, MG, and DFE) were proposed. The difference between PMG and MG are that MG seems to be more effective when there is a variation in the slope and intercept among the units in the panel, whereas, homogeneity of slope and intercepts among the units is assumed in the PMG. The third estimator (DFE) was proposed to be considered when the slope is constant, but there is variation in the intercepts across the units. Meanwhile, in order to determine which of the estimator to use, the Hausman test was recommended to be used.

\section{Empirical findings}

This study analysis commenced with the examination of the stationarity properties of the data. Both LLC and IMC unit root tests were employed and the results are summarized and presented in Table 2. The result as presented in Table 2 shows that economic freedom, human capital, and governance index are integrated at order 0, while GDP was found to be integrated at order 1 when tested with LLC unit root test. Meanwhile, when tested with IPS unit root test, only economic freedom was found to be integrated at order 0, while human capital, GDP, and governance were found to be I(1) variable. Summarily, the variable are mixed in the order of integration and none was I(2) variable, thus it's safe for further analysis

Table 2: Unit root test

\begin{tabular}{|l|l|l|l|l|l|l|}
\hline & \multicolumn{2}{|l|}{ Levin-Lin-Chu test } & & Im-Pesaran-Shin test & \\
\hline & Level & First Difference & $\begin{array}{l}\text { Order of } \\
\text { Integration }\end{array}$ & Level & First Difference & $\begin{array}{l}\text { Order } \\
\text { Integration }\end{array}$ \\
\hline Eco_Fre & $-4.281^{* *}$ & - & $\mathrm{I}(0)$ & $-4.377^{* *}$ & - & $\mathrm{I}(0)$ \\
\hline HCI & $-6.073^{* *}$ & - & $\mathrm{I}(0)$ & 0.245 & $-2.069^{* *}$ & $\mathrm{I}(1)$ \\
\hline InGDP & -1.2596 & $-7.1307^{* *}$ & $\mathrm{I}(1)$ & 3.933 & $-7.612^{* *}$ & $\mathrm{I}(1)$ \\
\hline Gov_index & $-3.5581^{* *}$ & - & $\mathrm{I}(0)$ & $-1.885^{*}$ & $-12.3026^{* *}$ & $\mathrm{I}(1)$ \\
\hline
\end{tabular}

$*, * *$ denotes $5 \%$ and $1 \%$ significance level

Source: Author's computation

In reference to Pesaran et al. (2004), cross-dependency test was conducted and the result presented in Table 3. The result for each of the variable under different test rejects the null hypothesis which is an indication of a high dependence among the panel variables.
The presence of cross-dependence implies that a shock in one of the SSA countries tends to be disseminated to other countries in the panel. 
Table 3: Cross-Dependency test

\begin{tabular}{|l|l|l|l|l|}
\hline Variable & Breusch-Pagan LM & Pesaran scaled LM & Bias-corrected scaled LM & Pesaran CD \\
\hline lnGDP & $6060.32^{* *}$ & $176.73^{* *}$ & $176.04^{* *}$ & $51.900^{* *}$ \\
\hline Eco_free & $4037.49^{* *}$ & $112.44^{* *}$ & $111.72^{* *}$ & $49.45^{* *}$ \\
\hline Gov_index & $2871.72^{* *}$ & $75.43^{* *}$ & $74.70^{* *}$ & -1.47 \\
\hline HCI & $10284.98^{* *}$ & $310.80^{* *}$ & $310.07^{* *}$ & $93.39^{* *}$ \\
\hline
\end{tabular}

Source: Author's computation

The existence of long-run relationship was examined with the Pedronicointegration test which consists of within-dimension (Panel) and between-dimension (Group) that were designed to test the cointegration among panel data. The results as presented in Table 4 reveals the significance ofthe $\mathrm{v}$, Rho, $\mathrm{t}$, and adf statistics which implies the establishment of long-run relationship among the variables "within-dimension". Similarly, the significance of Rho, t, and adf statistics at less than $1 \%$ confidence level indicates the confirmation of long-run relationship among the variables 'between-dimension'.

Table 4:Cointegration test

\begin{tabular}{|l|l|l|}
\hline Test Statistics & Panel & Group \\
\hline V & $-11.981^{* *}$ & \\
\hline Rho & $9.441^{* *}$ & $3.484^{* *}$ \\
\hline T & $-3.258^{* *}$ & $6.995^{* *}$ \\
\hline Adf & $2.538^{* *}$ & $3.776^{* *}$ \\
\hline
\end{tabular}

Source: Author's computation

In estimating the influence of governance, economic freedom and human capital on the economic growth of SSA region, this study rely on the work of Pesaran et al. (2004) which suggested the use of PMG, MG, and DFE for the estimation of dynamic panels in which the parameters are heterogeneous across groups. This study employed the three estimators for the study analysis and employed Hausman test to determine which of the three is appropriate. The hypothesis for the Hausman test indicates that PMG and MG estimates are not different statistically, but consider PMG to be more efficient when the p-value is greater than 0.05. Similarly, when testing PMG and DFE, the PMG is considered to be more efficient when the p-value is also greater than 0.05 . Therefore, from the result presented in 5, the p-value for Hausman test between PMG and MG shows to be greater than 0.05 (0.310), while the test between PMG and DFE also shows a p-value greater than 0.05 (0.999), thus we considered PMG to be more appropriate for this study estimation.

The results of the PMG estimator summarized and presented in Table 5 for both long and short-run influence of governance, economic freedom, and human capital on the economic growth of SSA region indicates that human capital drives positively and significantly the economic growth of SSA region at the long-run. The result demonstrates a positive and significant causal relationship between human capital and economic growth at the long-run at less than $1 \%$ confidence level. This result implies that a percentage increase in human capital in the region will improve the economic growth significantly in about $70 \%$. The findings of this study is consistent with previous studies (Absalyamova et al. 2015; Alatas\&Cakir, 2016; Ciuhu, 2016; Slaus\& Jacob, 2011) who agreed that the increase in human capital of any nation would foster the emergent of well-informed, social conscious people that would contribute meaningfully to the sustainability of the growth of their economy.

Similarly, the economic freedom and governance were found to be a significant determinant of economic growth in SSA at the longrun. The economic freedom was found for have a significant long- run causal relationship with economic growth at $1 \%$ confidence level, which implies that a percentage increase in economic freedom will drives about $18 \%$ of the economic growth of SSA at the long-run. Though, some previous studies found a mixed result (Ayal\&Karras, 1998; Carlsson\&Lundstrom, 2002; Derbel et al. 2011), our study is in agreement with some studies (Brkic et al. 2020, Doucouliagos\&Ulubasoglu, 2006; Graafland, 2020; Justeen, 2008; Medina-Moral \&Moutes-Gan, 2018; Mushtaq\& Ali Khan, 2018; Williamson \&Mathers, 2011) who found similar positive and significance influence of economic freedom on economic growth in their studies. Meanwhile, the study of Medina-Moral \&MoutesGan (2018) stressed further that the influence of economic freedom is not only found on economic growth, but in all stages of development. This corroborated the study finding of Tanin\& Mash (2017) who concluded in their study that economic freedom does not lag economic growth but leads. However, the positive impact of economic freedom found in our study contradict the study of Ali and Crain (2002) who found a negative influence of economic freedom on economic growth and argued that it is political freedom and civil liberty that influence economic growth and not economic freedom.

Moreover, this study reveals a positive and significant long-run relationship between governance and economic growth in SSA which is significant at less than $1 \%$ confidence level. The findings as presented in Table 5 shows that holding all other variable constant, a percentage increase in the governance will contribute about $11 \%$ increase in the economic growth of the region. This finding is consistent with some previous studies that have conducted similar work (Al Mamum et al. 2017; Adedokun, 2017; Glass and Newig, 2019; Fayissa\&Nsiah, 2017; Liu et al. 2018; Satayesh\&Daryaei, 2017). These studies agreed that governance is a social infrastructure that drives economic growth of any nation. The finding from this study corroborates the position of Murrell and Olson (1991) who stated that good governance could enable developing countries to catch up with developed countries if they could leverage on the effective use of their "late-mover". Therefore, the practice of good governance in SSA countries would no doubt drives the sustainability of economic growth in the region.

Meanwhile, as for the short-run estimates, the results as presented in Table 5 shows that only economic freedom shows a negative and significant causal relationship with economic growth. This is an indication that in the SSA region, a percentage change in the economic freedom will negatively affect the economic growth of the region by $1.2 \%$ in the short-run. In addition, the errorcorrection term (ECT) of the model was examined the possibility of the model returns to equilibrium in case of any shock. According to Odugbesan\&Rjoub (2019), the coefficient of the ECT must be negative and the $\mathrm{p}$-value is significant to indicate that the model is not explosive and will return to equilibrium in case of any disequilibrium. The result of the ECT as presented in Table 5 shows an ECT value of (-.108) which is also significant at less than $1 \%$ confidence level. This is an indication that in case of any disequilibrium, the model will return to equilibrium with the adjustment speed rate of $10.8 \%$. 
Table 5: Estimates of Long and short-run causal relationship

\begin{tabular}{|l|l|l|l|}
\hline $\begin{array}{l}\text { Dependent variable: } \\
\text { D.Ingdp }\end{array}$ & PMG & MG & DFE \\
\hline ECT & \begin{tabular}{l}
$-108^{* *}$ \\
\multicolumn{4}{|l|}{}
\end{tabular} & $-.310^{* *}$ & $-.068^{* *}$ \\
\hline Long-run estimates & $.724^{* *}$ & $2.208^{* *}$ & $.594^{* *}$ \\
\hline HC & $.180^{* *}$ & .164 & $.233^{* *}$ \\
\hline Eco_fre & $.110^{* *}$ & .129 & $.143^{* *}$ \\
\hline Gov_index & .186 & -.238 & -.146 \\
\hline Short-run estimates & $-.012^{*}$ & -.010 & $-.010^{*}$ \\
\hline D1.hc & .006 & -.002 & $.012^{*}$ \\
\hline D1.eco_fre & $.510^{* *}$ & $1.472^{* *}$ & $.331^{* *}$ \\
\hline D1.gov_index & 0.310 \\
\hline Constant & 0.999 \\
\hline Hausman Test (P-Value) & 32 & 32 \\
\hline \multicolumn{4}{|l|}{} \\
\hline & 704 & 704 & 704 \\
\hline Number of Countries & 32 \\
\hline Number of observations & \multicolumn{5}{|l}{} \\
\hline$* *$ denotes 5\% and 1\% significance level respectively
\end{tabular}

$*, * *$ denotes $5 \%$ and $1 \%$ significance level respectively.

Source: Author's computation

\section{Conclusion}

This study investigates the implications of governance, economic freedom, and human capital on the sustainability of economic growth in SSA using a panel data that spanned from 1996 to 2018, and employed PMG for the data analysis. This study shows a positive and significant causal relationship between governance and economic growth which is an indication that law and order in the society would ensure equality among every category of people which is imperative for sustainable development. Therefore, the government should ensure a good governance through a welldefined policy that would address the rule of law, absence of violence, reduction of corruption, transparency and accountability which are ingredients for a good business environment that will drives development, because the investors' confidence in the country will be enhanced.

The government of SSA countries should ensure the economic freedom for their people so that they can have business freedom, financial freedom, preservation of property right, monetary freedom, and trade freedom. These are the main ingredients of economic freedom that will boost investment opportunities, domestic and international trade, and in turn foster the sustainability of economic development in the region. Lastly, there is no doubt from the study finding on the significance of human capital that is adequately harnessed it has a potential of driving the sustainability of economic growth in SSA at the long-run. Meanwhile, there is a research without limitation. The limitation of this study lies in the estimator used which does not account for cross-dependency issue. Therefore, the future studies should employ some recent panel estimators that would address the crosssectional issue in panel data analysis. In addition, other variables that could determine the sustainable economic growth of SSA countries should be included in the model for subsequent studies, so as to avoid the variable omitted error. In conclusion, the policy makers and other stakeholders in SSA countries should strive towards achieving economic growth that will be sustainable by given priority to the human capital development in the region, especially education and health of the people, and ensure effectiveness of government, as well as creating an enabling environment for eco-friendly business.

\section{Data Availability}

The data used in this study is available at cited references in the manuscript

\section{Conflicts of Interest}

The Author declared no conflict of Interest

\section{References}

[1] Absalyamova, S. G., Absalyamov, T. B., Mukhametgalieva, C. F., \&Khusnullova, A. R. (2015).

Management of the sustainable development of human capital in the terms of macroeconomic instability. Procedia Economics and Finance, 24, 13-17.

[2] Adebiyi, M. A., \&Oladele, O. (2005). Public education expenditure and defence spending in Nigeria: An empirical investigation. http//www.saga. cornell.educ /saga/educconf/adebiyi.pdf (accessed July 27, 2020).

[3] Adedokun, Adeniyi Jimmy. 2017. Foreign aid, governance and economic growth in Sub-Saharan Africa: Does one cap fit all? African Development Review, 29: 184-96.

[4] Al Mamun, Md, KaziSohag, and M. Kabir Hassan. 2017. Governance, resources and growth. Economic Modelling, 63: 238-61.

[5] Alataş, S., \&Çakir, M. (2016). The effect of human capital on economic growth: A panel data analysis. YönetimBilimleriDergisi, 14(27), 539-555

[6] AlBassam, B. A. (2013). The relationship between governance and economic growth during times of crisis. European Journal of Sustainable Development, 2(2), 1-1.

[7] Ali- Abdel G.A. (2005).Building Human Capital for Economic Development in the Arab Countries. www.uis.unesco.org/template/pdf/ged/2005/gec. (Downloaded July 20 2020)

[8] Ali, A. M. and Crain, W. M. (2002).Institutional Distortion, Economic Freedom and Growth. CATO Journal, 21(3):415-426.

[9] Ayal, E. B. and Karras, G. (1998). Components of Economic Freedom and Growth: An Empirical Study. Journal of Developing Areas, 32(3):327-338.

[10] Barro, R. J., \& Lee, J. W. (2013). A new data set of educational attainment in the world, 1950- 2010. Journal of development economics, 104, 184-198.

[11] Barro, Robert J., and Jong-Wha Lee. (1993). "International Comparison of Educational Attainment" Journal of Monetary Economics, 32(3): 363-394.

[12] Bassanini, A., Scarpetta, S., \&Hemmings, P. (2001). Economic growth: the role of policies and institutions. Panel data evidence from OECD countries.

https://www.oecd.org/economy/growth/189140 3.pdf 
[13] Bayar, Y. (2017). Impact of openness and economic freedom on economic growth in the transition economies of the europeanunión. South-Eastern Europe Journal of Economics, 14(1).

[14] BediaAka and Jean C. Dumont (2008). 'Health Education and Economic Growth: Testing for Long Run Relationships and Causal Links', Applied Econometrics and International Development, Vol. 8, No. 2, pp. 101-113

[15] Benhabib J., Spiegel M.M, 1994 ,The Role of human capital in economic development. Evidence from aggregate cross-country time, Journal of Monetary Economics, 34, pp.143-173.

[16] Berggren, N. (2003). The benefits of economic freedom: A survey. Independent Review, 8, 193-211.

[17] Brkić, I., Gradojević, N., \&Ignjatijević, S. (2020). The Impact of Economic Freedom on Economic Growth?New European Dynamic Panel Evidence. Journal of Risk and Financial Management, 13(2), 26.

[18] Campos, J. Edgardo, Donald Lien, and Sanjay Pradhan. (1999). The impact of corruption on investment: Predictability matters. World Development, 27: 1059-67.

[19] Carlsson, F. and Lundstrom, S. (2002). Economic Freedom and Growth: Decomposing the Effects. Public Choice, 112(3/4):335-344.

[20] Ciuhu, A. M. (2016). Human capital and sustainability: current challenges. Eco-Economics Review, 2(1), 4348.

[21] Compton, R. A., Giedeman, D. C., \& Hoover, G. A. (2011). Panel evidence on economic freedom and growth in the United States.European Journal of Political Economy, 27, 423-435.

[22] Dahlström, Carl, Victor Lapuente, and Jan Teorell. (2012). The merit of meritocratization: Politics, bureaucracy, and the institutional deterrents of corruption. Political Research Quarterly, 65: 656-68.

[23] De La Fuente Á, Domenéch A., (2000). A Human capital in growth regressions: how much difference does data quality make? Economic Department Working Paper No262, Paris: $\quad$ OECD, 2000 (ECO / WKP (2000) 35);

[24] De La Fuente Á, Domenéch A., (2006). Human capital in growth regressions: how much difference does data quality make?,Journal of the European Economic Association, 4(1), pp.1-36.

[25] Derbel, H., Abdelkafi, R., \&Chkir, A. (2011). The effects of economic freedom components on economic growth: an analysis with a threshold model. J. Pol. \& L., 4, 49.

[26] Dhaoui, I. (2019). Good governance for sustainable development. MPRA Paper No. 92544. Available at: https://mpra.ub.uni-muenchen.de/92544/

[27] Doucouliagos, C. and Ulubasuglou, M. A. (2006). Economic Freedom and Economic Growth: Does Specification Make a Difference? European Journal of Political Economy, 22 (1).

[28] Easton, S. and Walker, M. (1997).Income, Growth, and Economic Freedom.The American Economic Review, 87 (2):328-332.

[29] Evans, Peter, and James E. Rauch. (1999). Bureaucracy and growth: A cross national analysis of the effects of "Weberian" state structures on economic growth. American Sociological Review, 64: 748-65.

[30] Fayissa, Bichaka, and Christian Nsiah. (2013). The impact of governance on economic growth in Africa. The Journal of Developing Areas, 47: 91-108.

[31] Feenstra, R. C., Inklaar, R., \&Timmer, M. P. (2015).The next generation of the Penn World Table. American economic review, 105(10), 3150-82.

[32] Freire-Serén, M. J. (1999). Human capital accumulation and economic growth.Investigaciones Economicas, Vol. 25, No. 3, p. 585-602

[33] Funke M., H. Strulik, (2000). On endogenous growth with physical capital, human capital and product variety.European Economic Review, 44 (2000), pp. 491515 ;

[34] Glass, L. M., \&Newig, J. (2019). Governance for achieving the Sustainable Development Goals: How important are participation, policy coherence, reflexivity, adaptation and democratic institutions?. Earth System Governance, 2, 100031.

[35] Graafland, J. (2020). When Does Economic Freedom Promote Well Being? On the Moderating Role of Long-Term Orientation. Social Indicators Research, 149(1), 127-153.

[36] Gwartney, J., Hall, J., \& Lawson, R. (2019). Economic freedom of the world: 2017 annual report. Retrieved July 19, 2020, from https://www.fraserinstitute.org/studies/econo micfreedom-of-the-world -2019-annual-report.

[37] Hall, Robert E., and Charles I. Jones. (1999). Why do some countries produce so much more output per worker than others? Quarterly Journal of Economics, 114: 83-116

[38] Huynh, Kim P., and David T. Jacho-Chávez. (2009). Growth and governance: A nonparametric analysis. Journal of Comparative Economics, 37: $121-43$.

[39] Im, K.S., Pesaran, M.H. and Shin, Y., (2003). Testing for Unit Roots in Heterogeneous Panels. Journal of Econometrics, 115(1), pp.53-74.

[40] Islam, S. (1996).Economic Freedom, Per Capita Income and Economic Growth.Applied Economics Letters, 3(9):595-597.

[41] James, G., Lawson, R., \& Hall, J. (2012). Economic freedom of the world: 2012 annual report. Vancouver: Fraser Institute.

[42] Justesen, M. K. (2008). The Effect of Economic Freedom on Growth Revisited: New Evidence on Causality From a Panel of Countries 1970-1999. European Journal of Political Economy, 24(3):642-660.

[43] Kaufmann, D., Kraay, A., \&Mastruzzi, M. (2010). The worldwide governance indicators: Methodology and analytical issues. Draft policy research. Working Paper.Database from World Bank. Retrieved July 4, 2020, from http://info.worldbank.org/governance/wgi/pdf/ WGI.pd

[44] Knack, Stephen, and Philip Keefer. (1995). Institutions and economic performance: Cross- country tests using alternative institutional measures. Economics \& Politics, 7: 207-27. 
[45] Levine, A., Lin, C. and Chu, C., 2002. Unit Root Tests in Panel Data: Asymptotic and Finite Sample Properties. Journal of Econometrics, 108(1), pp. 1-24.

[46] Liu, J., Tang, J., Zhou, B., \& Liang, Z. (2018). The effect of governance quality on economic growth: Based on China's provincial panel data. Economies, 6(4), 56.

[47] Liu, Mingxing, Dong Zhang, Tao Qian, and Qi Zhang.(2013). Informal power structure and economic policy of local government in China.Sociological Studies, 5: 26-52.

[48] Lucas, Robert E. Jr. (1988). On the Mechanics of Economic Development.Journal of Monetary Economics, 22 (July 1988): 3-42.

[49] Mankiw N. G; Romer D, Weil D.N, (1992). Contribution to the Empirics of Economic Growth, The Quarterly Journal of Economics, Vol. 107, No. 2 (May, 1992), pp. 407-437;

[50] Medina-Moral, E., \& Montes-Gan, V. J. (2018).Economic freedom, good governance and the dynamics of development. Journal of Applied Economics, 21(1), 44-66.

[51] Murrell, Peter, and Mancur Olson. (1991). The devolution of centrally planned economies. Journal of Comparative Economics, 15: 239-65.

[52] Mushtaq, S., \& Ali Khan, R. E. (2018). Economic freedom and sustainable development: A Panel

Data Analysis. The Pakistan Journal of Social Issues. Special Issue, 89-97.

[53] Odugbesan, J. A., \&Rjoub, H. (2019a). Relationship among HIV/AIDS Prevalence, Human Capital, Good Governance, and Sustainable Development: Empirical Evidence from Sub- Saharan Africa. Sustainability, 11(5), 1348.

[54] ODUGBESAN, J. A., \& RJOUB, H. (2019b). THE CAUSAL RELATIONSHIP BETWEEN ECONOMIC GROWTH AND REMITTANCE IN MINT COUNTRIES: AN ARDL BOUNDS TESTING APPROACH TO COINTEGRATION. Journal of Academic Research in Economics, 11(2).

[55] Odugbesan, J. A., \&Rjoub, H. (2020).Evaluating HIV/Aids prevalence and sustainable development in sub-Saharan Africa: the role of health expenditure. African Health Sciences, 20(2), 568-578.

[56] Rjoub, H., Ifediora, C. U., Odugbesan, J. A., Iloka, B. C., Xavier Rita, J., Dantas, R. M., ... \& Martins, J. M. (2021). Implications of Governance, Natural Resources, and Security Threats on Economic Development: Evidence from Sub-Saharan Africa. International Journal of Environmental Research and Public Health, 18(12), 6236.

[57] Olson, Mancur, Jr., Naveen Sarna, and Anand V. Swamy. (2000). Governance and growth: A simple hypothesis explaining cross-country differences in productivity growth. Public Choice, 102: 341-64.

[58] Omojimite, B. U. (2011). Building human capital for sustainable economic development in Nigeria. Journal of Sustainable Development, 4(4), 183.

[59] Pelinescu, E. (2015). The impact of human capital on economic growth. Procedia Economics and Finance, 22(1), 184-190.
[60] Persyn, D., \&Westerlund, J. (2008). Error-correctionbased cointegration tests for panel data. The STATA journal, 8(2), 232-241.

[61] Pesaran, M. H., Schuermann, T., \& Weiner, S. M. (2004).Modeling regional interdependencies using a global error-correcting macroeconometric model. Journal of Business \& Economic Statistics, 22(2), 129-162.

[62] Pritchett, L. (1999). Where Has All the Education Gone? Policy Research Working Paper, World Bank, Washington D.C.

[63] Rauch, James E. (1995). Bureaucracy, infrastructure, and economic growth: Evidence from U.S. cities during the progressive era. American Economic Review, 85: 968 79.

[64] Raul Ramos, JordiSurinach and Manuel Artis (2009). Regional Economic Growth and Human Capital: The Role of Overeducation',The Institutefor the Studyof LaborDiscussion Paper Series, No. 4453.

[65] Rehme, G. (2007). Education, Economic Growth and Measured Income Inequality.Economica, 74, 493- 514.

[66] Riley G, 2012, Economic Growth - The Role of Human \& Social Capital, Competition \& Innovation.http://www.tutor2u.net/economics/r evisionnotes/a2-macro-economic-growthcapital.html, Accessed July 27, 2020;

[67] Rode, M., \&Coll, S. (2012). Economic freedom and growth: Which variables matter the most? Constitutional Political Economy, 23, 95-133.

[68] Romer, Paul M. (1990). Endogenous Technological Change .Journal of Political Economy 98(5) part II: S71-S102.

[69] Seldadyo, Harry, Emmanuel PanduNugroho, and Jakob De Haan. 2007. Governance and growth revisited. Kyklos, 60: 279-90.

[70] Setayesh, Mohammad Hossein, and Abbas Ali Daryaei.(2017). Good governance, innovation, economic growth and the stock market turnover rate. The Journal of International Trade \& Economic Development, 26: 829-50.

[71] Shao, Chuanlin. (2016). Chinese-style decentralization, marketization process and economic growth.Statistical Research, 33: 63-71.

[72] Šlaus, I., \& Jacobs, G. (2011).Human capital and sustainability. Sustainability, 3(1), 97-154. Adusah-Poku, F., (2016). Which form of Foreign Capital Inflows enhance Economic Growth? Empirical evidence in sub Saharan Africa.Asian Economic and Financial Review, 6(10), pp. 557-570.

[73] Tanin, T. I., \&Masih, M. (2017). Does economic freedom lead or lag economic growth. Evidence from Bangladesh.MPRA Paper, (79446), 28.

[74] Williamson, C. R. and Mathers, R. L. (2011).Economic Freedom, Culture and Growth.Public Choice, 148(34):313-335.

[75] World Bank (2020).World Bank development indicators. http://databank. worldbank. org/data/home.aspx

[76] World Governance Indicators. 2020. Available online: www.govindicators.org (accessed on $16 \quad$ June 2020). 
[77] Zhang, Hong, and Youqiang Wang. (2013). Governance and economic growth: Evolution of the relationship between different income stages. Comparative Economic \& Social Systems, 3: 151-59.
[78] Zhang, Yishan, and Weisheng Yu.(2009). Economic power structure and optimal allocation of productive factors.Economic Research Journal, 6: $65-72$. 